\title{
Biochemical and Morphological Changes during the Growth Kinetics of Araucaria angustifolia Suspension Cultures
}

\author{
André Luis Wendt dos Santos, Vanildo Silveira, Neusa Steiner, Marcelo Maraschin and \\ Miguel Pedro Guerra* \\ Departamento de Fitotecnia; Laboratório Fisiologia do Desenvolvimento e Genética Vegetal; Universidade \\ Federal de Santa Catarina; C.P.: 476; 88034-001; Florianopolis - SC - Brasil
}

\begin{abstract}
Embryogenic cultures of Araucaria angustifolia were established in a BM liquid medium supplemented with $2 \mu M$ 2,4-dichlorophenoxyacetic acid, $1 \mu M$ 6-benzylaminopurine and $1 \mu M$ kinetin (BM2) and in a BM medium free of growth regulators (BMO). During 42 days in culture, the cell growth pattern of both cultures was similar. The pH of the culture medium of both BMO and BM2 underwent progressive reduction during culture time. For both the embryogenic cultures a preferential uptake of glucose in the late stages of cell growth kinetics was observed. The extracellular protein content was similar for both the embryogenic cultures. Acetocarmine and Evan's blue double stain showed major differences for early somatic embryo organisation, in which only the embryogenic culture grown in a liquid culture medium free of plant growth regulators showed the presence of bipolar somatic proembryos.
\end{abstract}

Key words: Araucariaceae, glucose, $\mathrm{pH}$ changes, protein, somatic embryogenesis

\section{INTRODUCTION}

A somatic embryogenesis protocol has been developed for Araucaria angustifolia, a threatened subtropical conifer species from South Brazil. However, up to now, only somatic embryos in early developmental stages have been obtained (Guerra et al., 2000; Santos et al., 2002; Silveira et al., 2002). The existence of only a few reports related to somatic embryogenesis in the Araucariaceae family (Guerra et al., 2000) as well as on the environmental stimuli and signalling events that trigger and regulate plant embryogenesis (Veena and Rao, 2000), are the main limitations to be overcome.

Cell suspension cultures are considered as the most flexible technique for plant cell tissue culture for scale-up operations (Wickremesinhe and Arteca, 1994). Suspension cultures show a faster cell growth than the cultures on a gelled medium, reducing manipulation and the risk of contamination (Silveira et al., 2004). However, to use the embryogenic suspension culture as a reproducible tissue culture system, with a potential for large-scale production, requires characterization of growth parameters, nutrient requirements, and studies on cell metabolism.

The purpose of this work was to evaluate the parameters associated to growth dynamics, growth regulators effects, $\mathrm{pH}$ changes of the culture medium, extracellular proteins and glucose in two

\footnotetext{
* Author for correspondence: mpguerra@cca.ufsc.br
} 
embryogenic suspension cultures of A. angustifolia. The hystodifferentiation of such cultures, as affected by these parameters, was also investigated.

\section{MATERIAL AND METHODS}

\section{Culture medium}

The medium was composed by BM basal salts (Gupta and Pullman, 1991) supplemented with 500 mg.L-1 casein hydrolysate, 1 g.L-1 myo-inositol, 1 g.L-1 L-glutamine, 30 g.L-1 sucrose and 2 g.L-1 Phytagel (Sigma ${ }^{\circ}$ ). It was sterilized by autoclaving at $121^{\circ} \mathrm{C}$ for $15 \mathrm{~min}$. Stock solutions of L-glutamine, casein hydrolisate and myoinositol were filter sterilized and added to the medium after autoclaving.

\section{Embryogenic tissue initiation and maintenance}

The induction of embryogenic cultures was performed as reported by Santos et al., (2002). Immature zygotic embryos excised from seeds of A. angustifolia were placed on Petri dishes $(100 \mathrm{x}$ $15 \mathrm{~mm}$ ) containing $20 \mathrm{~mL}$ of $\mathrm{BM}$ basal salts supplemented with or without plant growth regulators (PGR), 2,4-dichlorophenoxyacetic acid (2,4-D) $(5 \mu \mathrm{M})$, 6-benzylaminopurine (BA) (2 $\mu \mathrm{M})$ and kinetin (Kin) $(2 \mu \mathrm{M})$ in the dark at $25 \pm 2$ ${ }^{\circ} \mathrm{C}$. For maintenance, embryogenic cultures initiated without growth regulators were subcultured in the same medium used in the induction phase (BM0). Embryogenic cultures induced in the medium containing growth regulators were maintained on BM medium supplemented with 2,4-D $(2 \mu \mathrm{M})$, BA $(1 \mu \mathrm{M})$ and Kin $(1 \mu \mathrm{M})(\mathrm{BM} 2)$. Sixty days after starting the induction phase embryogenic suspension cultures were established using $500 \mathrm{mg}$ (fresh weight) of embryogenic cultures maintained on BM0 and BM2 culture medium. Tissue clumps were breakup using forceps and scarpel and then dispersed in adapted nipple-flasks containing 120 $\mathrm{mL}$ of liquid culture medium (BM0 or BM2) incubated on a rotating disc at slow rotation (1 rpm) in the dark at $25 \pm 2{ }^{\circ} \mathrm{C}$.

\section{Cell growth dynamic}

The cellular growth was assayed by the sedimented cell volume technique (SCV) using graduated centrifuge tubes adapted to nippleflasks. The SCV was measured over 42 days of culture (three day intervals). The morphological and histochemical characteristics of embryogenic cells suspensions BM0 and BM2 were monitored by the double staining procedure as described by Gupta and Durzan (1987).

\section{Growth parameters}

Changes in $\mathrm{pH}$ in the culture medium, extracellular protein and glucose were measured over a 40-day culture period (five day intervals). Suspension cultures BM0 and BM2 were poured through a $200 \mu \mathrm{m}$ cell dissociation sieve, following centrifugation at $3500 \mathrm{~g}$ for $15 \mathrm{~min}$. Aliquots $(10 \mathrm{ml})$ of supernatant were used for the measurement of $\mathrm{pH}$, the remains being frozen at $20{ }^{\circ} \mathrm{C}$ for later analysis. Extracellular proteins were precipitated with the addition of 1.5 volume of cold absolute ethanol and kept at $4{ }^{\circ} \mathrm{C}$ overnight. Following centrifugation $(6500 \mathrm{~g}, 10$ min, $4{ }^{\circ} \mathrm{C}$ ), the pellet was dissolved in $250 \mu \mathrm{L}$ of $50 \mathrm{mM}$ dibasic sodium phosphate buffer ( $\mathrm{pH}$ 7.0). Protein levels were determined by the dye-binding method of Bradford (1976) with bovine serum albumin as a standard. Glucose concentration in the medium was determined using a commercial kit (Analiza ${ }^{\circledR}$, Brazil) by measuring the absorbance at $630 \mathrm{~nm}$ (Shimadzu spectrophotometer, model 1203).

\section{Data analysis}

All analyses were performed in triplicate. All the experiments were repeated twice with similar results. The data presented are of a single representative experiment. Mean and standard errors were applied to analyze the data.

\section{RESULTS AND DISCUSSION}

\section{Cell growth dynamics}

BM0 and BM2 embryogenic suspension cultures showed a similar growth rate during 42 days in culture, presenting an increase of SCV 0.92 and $0.95 \mathrm{~mL}$, respectively. BM0 embryogenic showed the presence of bipolar pro-somatic embryos (Fig. 1A).

However, during the culture period, a random brown/red cell clumps formation was observed. This cell formation was assessed by doublestaining procedures and later on led to a loss in pro-embryo morphology. These features were also described in a previous work with embryogenic cultures of A. angustifolia, cultured in a semi-solid culture medium free of growth regulators (Santos 
et al., 2002). In Taxus brevifolia suspension cultures, the presence of random and unpredictable red-coloured exudates eventually led to cell death (Wickremesinhe and Arteca, 1994). Comparatively, BM2 suspension cultures showed a less developed pro-embryogenic morphology
(Fig. 1B) and great variation in the growth pattern among the flasks (repetitions) (Fig. 2). BM0 suspension cultures did not show a significant exponential growth phase, and at the end of experiment, SCV was still increasing (Fig. 2).

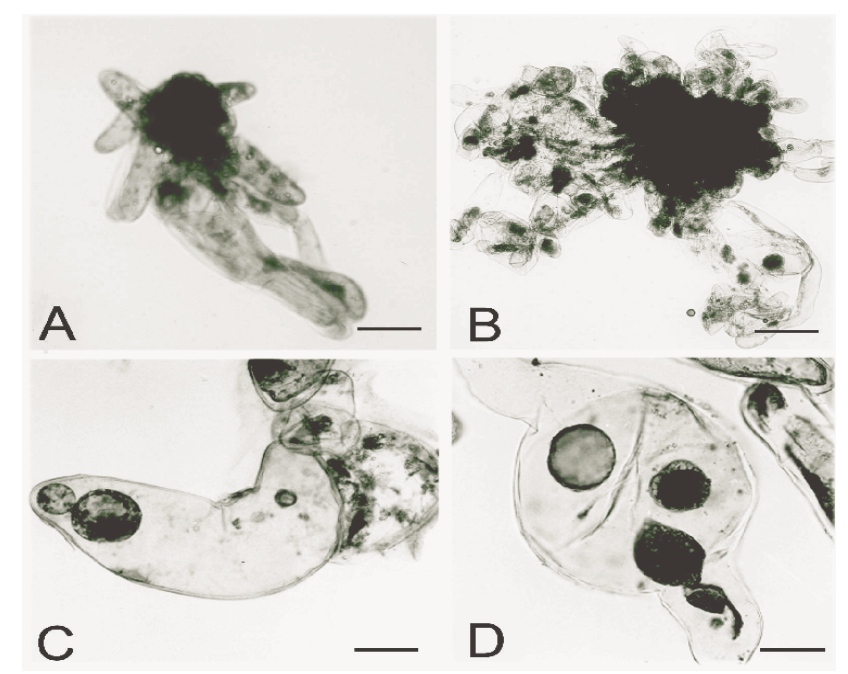

Figure 1 - A-D - Cell line characterization in embryogenic suspension cultures of A. angustifolia A) Pro-embryos in BM culture medium free of growth regulators (BM0) (bar. $33.3 \mu \mathrm{m}$ ) B) Pro-embryo in BM culture supplemented with 2,4-D $(2 \mu \mathrm{M})$, BA $(1 \mu \mathrm{M})$ and Kin $(1$ $\mu \mathrm{M})(\mathrm{BM} 2)$ (bar. $33.3 \mu \mathrm{M}) \mathrm{C}$ ) Cylindrical cell containing two free nuclear stages (bar. $66.7 \mu \mathrm{M}) \mathrm{D})$ Migration of free nuclei for possible formation of early somatic embryos (bar. $66.7 \mu \mathrm{M}$ ).

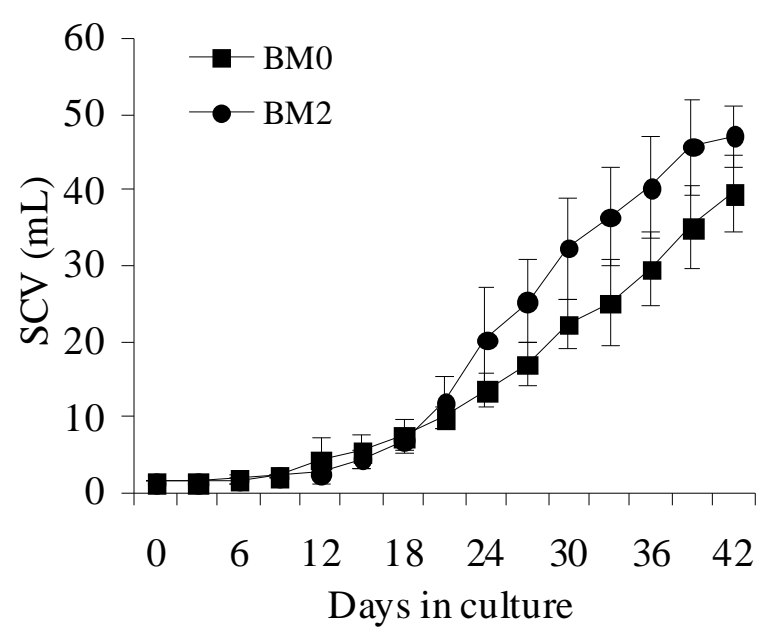

Figure 2 - Sedimented cell volume (SCV) of embryogenic cultures of A. angustifolia maintained in a BM culture medium free of growth regulators (BM0) and in a BM culture medium supplemented with 2,4-D $(2 \mu \mathrm{M})$, BA $(1 \mu \mathrm{M})$ and $\mathrm{Kin}(1 \mu \mathrm{M})(\mathrm{BM} 2)$. The bar indicates the standard deviation from mean values derived from three replicates. 
Embryogenic cultures of $A$. angustifolia, as in Picea abies (Jalonen and von Arnold, 1991) were classified into two main groups based on cell morphology, cytodifferentiation and growth characteristics. A. angustifolia embryogenic cultures maintained in repetitive cell division cycles in a liquid medium supplemented with growth regulators featured a morphology corresponding to group B (somatic embryo less developed) and embryogenic cultures maintained in a culture medium free of growth regulators presented the morphology of group A (bipolar somatic embryos). When embryogenic cultures of Pinus pinaster were maintained in liquid medium, it produced less developed embryogenic cultures (Group B) that further grew better (Bercetche and Pâques, 1995). Type A embryogenic cultures of Picea abies showed a lower growth rate in a liquid medium than corresponding type B cultures (Egertsdotter et al., 1993).

\section{Cell morphology and histodifferentiation}

Previous work with A. angustifolia, showed different cellular patterns consisting of small densely cytoplasmic cells (embryogenic cells) and highly vacuolated and elongated cells (suspensor cells) (Astarita and Guerra, 2000; Steiner et al., 2005). In the present work, cylindrical, elongated and binucleated cells with 150 to $200 \mu \mathrm{m}$ length were observed (Figs. 1C and 1D). In Larix leptolepis, long binucleated cells underwent a continuous process of cellular division resulting in the development of adventitious somatic proembryos (Ogita et al., 1997). Diploid parthenogenesis occurs in somatic cells conifer suspension cultures. This form of apomitic parthenogenesis, observed in A. angustifolia, was latent in Picea abies. This was associated to the presence of embryonal tube cells (Durzan et al., 1994).

\section{Extracellular proteins}

The extracellular protein content $\left(\mu \mathrm{g} \cdot \mathrm{mL}^{-1}\right)$ was quite similar for BM0 and BM2 cultures (Fig. 3) with a slight increment in BM0 cultures. For BM2, an increase in extracellular protein levels was observed during the exponential growth phase, at the beginning of the linear growth phase and also at the transition from linear to a stationary growth phase.

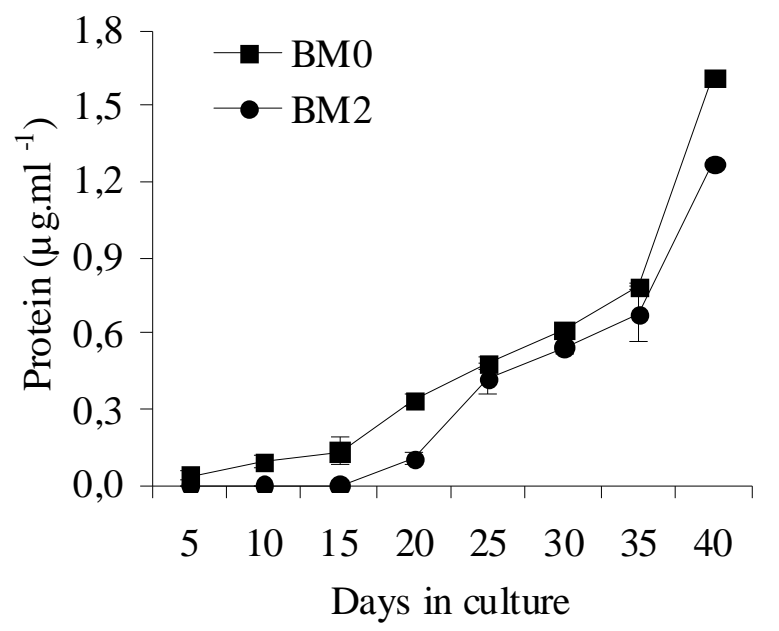

Figure 3 - Extracellular protein content derived from BM0 and BM2 embryogenic cultures of $A$. angustifolia maintained in a BM culture medium, respectively free of growth regulators (BM0) and supplemented with 2,4-D $(2 \mu \mathrm{M})$, BA $(1 \mu \mathrm{M})$ and Kin $(1 \mu \mathrm{M})(\mathrm{BM} 2)$. The bar indicates the standard deviation from mean values obtained from three replicates.

The accumulation of extracellular proteins in the culture medium could be related to an intensive extrusion process attributed to biochemical modifications or structural cell changes resulting in cellular lysis as suggested by Astarita and
Guerra (2000). In Picea abies, differences in the cellular composition of cell line type A (high proportion of meristematic cell) and type B (high proportion of vacuolated cells) were also associated to a different pattern of secretion of 
proteins into the culture medium (Find et al., 1998). In Catharanthus roseus, cell cultures containing growth regulators did not show significant changes in polypeptide patterns, and changes in in vitro polypeptide synthesis were fewer than those encountered in vivo (Ouelhazi et al., 1994).

\section{Extracellular glucose}

A decrease in the glucose content $\left(\mu \mathrm{g} \cdot \mathrm{mL}^{-1}\right)$ in late stages of the cellular growth (Fig. 4) was observed for both cultures. For BM2 cultures, after a variation period between the $5^{\text {th }}$ and $15^{\text {th }}$ day (exponential growth phase), the glucose content peaked on the $20^{\text {th }}$ day and then started to decline. An accumulation of glucose in the culture medium was also observed until the $30^{\text {th }}$ day in BM0 cultures. After this, a decrease in the levels of this sugar, was seen.

Embryogenic cultures of A. angustifolia maintained in a BM2 culture showed different uptake and utilization patterns for different sugars, fructose being rapidly metabolised, followed by glucose depletion (Astarita and Guerra, 2000). In Taxus brevifolia suspension cultures, the hydrolysis of sucrose was associated to the utilization of glucose and the fructose availability. This was coincident with the exponential phase of the suspension cultures (Wickremesinhe and Arteca, 1994). Other Gymnosperms also showed a selective pattern of glucose and fructose uptake. Suspension cells of Picea mariana preferentially metabolised glucose while in Picea-glauca engelmannii, fructose was preferentially utilized (Tautorus et al., 1994).

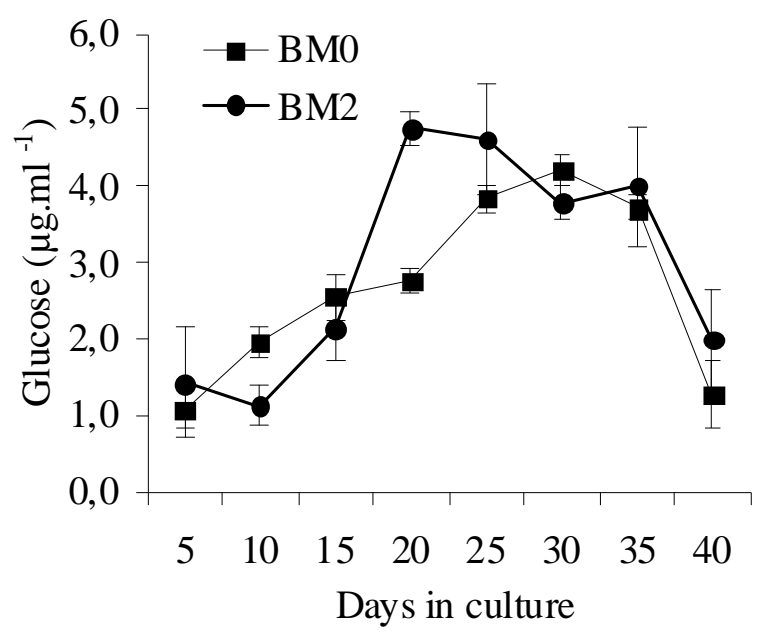

Figure 4 - Glucose concentration in embryogenic cultures of A. angustifolia cultured in a BM culture medium free of growth regulators (BM0)and BM medium supplemented with 2,4-D $(2 \mu \mathrm{M})$, BA $(1 \mu \mathrm{M})$ and $\operatorname{Kin}(1 \mu \mathrm{M})$ (BM2). The bar indicates the standard deviation from mean values derived from three replicates.

Heterotrophic plant cells growing in suspension cultures are dependent on the import of sugars from the medium (Krook et al., 1998). Sucrose is the common carbon source in most plant tissue cultures (Wang et al., 2000). However, sucrose is not always the best carbohydrate source (Maataoui et al., 1998). Up to now, only sucrose and fructose have supported $A$. angustifolia embryogenic cell growth (Astarita and Guerra, 1998), but maltose associated with PEG 3350 was beneficial to somatic embryo development (Santos et al., 2002, Steiner et al., 2005). It was suggested that the slow hydrolysis of maltose was the biochemical signal leading to the formation of somatic embryos. On the contrary, rapid hydrolysis of sucrose could increase the content of hexoses and storage compounds, directing the cells to a fast proliferation rates (Blanc et al., 2002). In Picea rubens, fructose was considered the best sugar for embryo development (Tremblay and Tremblay, 1991) while for Abies alba, lactose and sorbitol favoured the formation of somatic embryos up to early cotyledonary stage (Schuller et al., 2000). 


\section{pH}

The $\mathrm{pH}$ value in the culture medium for $\mathrm{BM} 0$ and BM2 embryogenic cultures underwent progressive reduction during the culture period, showing higher values for BM0 culture (Fig. 5) from 20 days. A decrease in the $\mathrm{pH}$ values in the BM2 culture ranging from 5.43 (after autoclaving) to 3.09 on the $40^{\text {th }}$ day (stationary phase) was observed. These values ranged from 5.39 to 4.22 in the BM0 cultures.

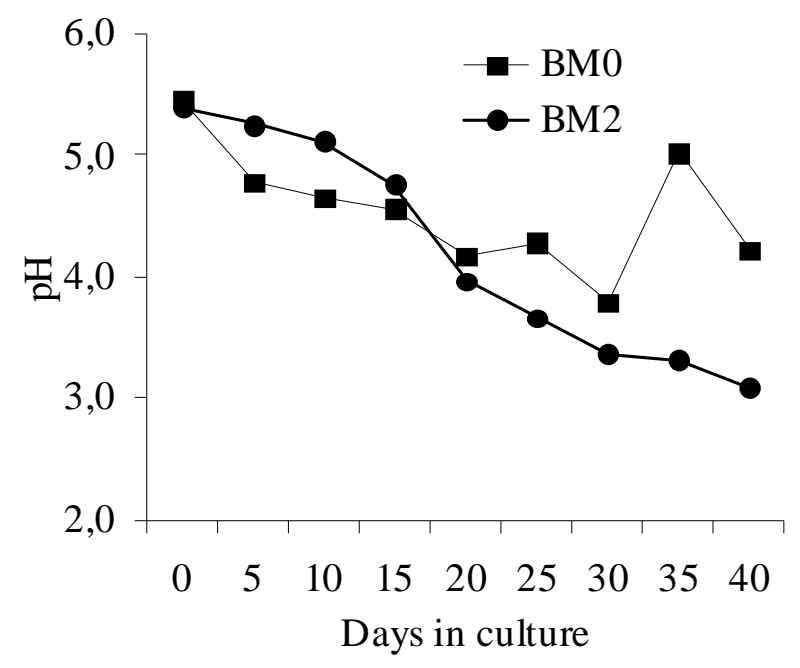

Figure 5 - pH values in the culture medium of $A$. angustifolia embryogenic cultures maintained in $\mathrm{BM}$ culture medium free of growth regulators (BM0) and in culture medium supplemented with 2,4-D $(2 \mu \mathrm{M})$, BA $(1 \mu \mathrm{M})$ and Kin $(1 \mu \mathrm{M})(\mathrm{BM} 2)$.

Plant cell cultures are sensitive to $\mathrm{pH}$ and the external levels affect the uptake of auxin, metabolites, and nutrients in the cells and can shift the cell's internal pH (Link and Cosgrove, 1998). Changes in the $\mathrm{pH}$ medium are normally correlated to different cell uptakes of inorganic nitrogen source to ammonium $\left(\mathrm{NH}_{4}{ }^{+}\right)$and nitrate $\left(\mathrm{NO}_{3}{ }^{+}\right)$. The preferential cell uptake of $\mathrm{NH}_{4}{ }^{+}$over $\mathrm{NO}_{3}{ }^{-}$, promotes the excretion of $\mathrm{H}^{+}$to the medium culture and consequently affects the medium acidification. However, the presence of amino acids and casein hydrolysate and their uptake by the cell affects the acidification in a similar way to $\mathrm{NH}_{4}{ }^{+}$cell uptake (George, 1993). In conifers, Lglutamin and casein hydrolysate are frequently supplemented to the culture medium during the induction, maintenance and maturation of somatic embryos (Feirer, 1995) and they are preferentially consumed in a culture medium with suboptimal inorganic nitrogen levels (Barret et al., 1997). In Picea abies, differences in $\mathrm{pH}$ levels between type $\mathrm{A}$ and $\mathrm{B}$ embryogenic cultures were observed. The $\mathrm{pH}$ of type B cells culture medium stabilized about $1.5 \mathrm{pH}$ units below the $\mathrm{pH}$ of type A cells (Find et al., 1998).
In conclusion, in the absence of PGR, it was possible to observe the formation of bipolar early somatic embryos. Additionally, a different cell growth dynamics and a progressive reduction of $\mathrm{pH}$ values in the culture medium supplemented (BM2) or free of PGR (BM0) was observed. For both the embryogenic cultures, glucose uptake was preferentially observed in the late stages of cell growth kinetics. The extracellular protein profile was similar in both the cultures, although a specific set of extracellular proteins could be involved in the induction of early somatic embryos in embryogenic cultures grown in liquid medium, free of PGR.

\section{RESUMO}

Culturas embriogênicas de Araucaria angustifolia foram estabelecidas em meio de cultura líquido BM suplementado com $2 \mu \mathrm{M}$ Ácido 2,4 Diclorofenoxiacético, $1 \mu \mathrm{M}$ 6-Benzilaminopurina e $1 \mu$ M Cinetina (BM2) e em meio BM isento de reguladores de crescimento (BM0). Durante 42 
dias de cultivo, o padrão de crescimento celular em ambas as culturas foi similar. $\mathrm{O} \mathrm{pH}$ do meio de cultura BM0 e BM2 sofreu uma progressiva redução durante o período de cultivo. Em ambas as culturas embriogênicas foram observadas um consumo preferencial de glicose no período final da curva de crescimento celular. O nível de proteínas extracelulares foi similar para ambas as culturas embriogênicas. A dupla coloração com carmin acético e azul de Evans revelou diferenças na organização das linhagens celulares embriogênicas, sendo que a presença de proembriões somáticos bipolares foi apenas evidenciada nas culturas embriogênicas mantidas em meio de cultura líquido sem reguladores de crescimento.

\section{REFERENCES}

Astarita, L. V. and Guerra, M. P. (1998), Early somatic embryogenesis in Araucaria angustifolia - induction and maintenance of embryonal-suspensor mass cultures. Brazilian Journal of Plant Physiology, 10, 113-118.

Astarita, L. V. and Guerra, M. P. (2000), Conditioning of culture medium by suspension cells and formation of somatic proembryo in Araucaria angustifolia (Coniferae). In Vitro Cellular Developmental Biology Plant, 36, 194-200.

Barret J. D.; Park, Y. S. and Bonga, J. M. (1997), The effectiveness of various nitrogen sources in Withe Spruce [Picea glauca (Moench) Voss] somatic embryogenesis. Plant Cell Reports, 16, 411-415.

Bercetche, J. and Pâques, M. (1995), Somatic embryogenesis in Maritime pine (Pinus pinaster). In: Jain, S. M.; Gupta, P. and Newton, R. (Ed.). Somatic Embryogenesis in Woody Plants. Dordrecht. Kluwer Academic Publishers. pp. 221-242.

Blanc G.; Lardet L.; Martin A.; Jacob J.L. and Carron M.P. (2002), Differential carbohydrate metabolism conducts morphogenesis in embryogenic callus of Hevea brasiliensis (Mull. Arg.). Journal of Experimental Botany, 53, 1453-1462.

Bozhkov, P. V.; Ahn, I. S. and Park, Y. G. (1997), Two alternative pathways of somatic embryo origin from polyembryonic mature stored seeds of Pinus koraiensis Sieb et Zucc. Canadian Journal of Botany, 75, 509-512.

Bradford, M. M. (1976), A rapid and sensitive method for the quantification of microgram quantities of protein utilising the principle of protein-dye binding. Analytical Biochemistry, 72, 248-253.
Durzan, D. J.; Jokinen, K.; Guerra, M. P.; Santerre, A.; Chalupa, V. and Havel, L. (1994), Latent diploid parthenogenesis and parthenote cleavage in eggequivalents of Norway Spruce. International Journal of Plant Science, 155, 677-688.

Egertsdotter, U.; Mo, H. and von Arnold, S. (1993), Extracellular proteins in embryogenic suspension cultures of Norway spruce (Picea abies). Physiologia Plantarum, 88, 315-321.

Feirer, R. P. (1995), The Biochemistry of Conifer Embryo Development: Amino acids, polyamines and storage proteins. In: Jain, S. M.; Gupta, P. and Newton, R. (Ed.). Somatic Embryogenesis in Woody Plants. Dordrecht: Kluwer Academic Publishers. pp. 317-359.

Find, J. I.; Norgaard, J. V. and Krogstrup, P. (1998), Growth parameters, nutrient uptake and maturation capacity of two cell-lines of Norway Spruce (Picea abies) in suspension culture. Journal of Plant Physiology, 152, 510-517.

George E. F. (1993), Plant Propagation by Tissue Culture Part 1. England: Exeegetics.

Guerra, M. P.; Silveira, S.; Santos, A. L. W.; Astarita, L. V. and Nodari, R. O. (2000), Somatic embryogenesis in Araucaria angustifolia (Bert) O. Ktze. In: Jain, S. M.; Gupta, P. and Newton R. (Ed.). Somatic Embryogenesis in Woody Plants. Dordrecht: Kluwer Academic Publishers. pp. 457-478.

Gupta, P. K. and Durzan, D. J. (1987), Biotechnology of somatic polyembryogenesis and plantlet regeneration in loblolly pine. Bio/Technology, 5, 147151.

Gupta, P. K. and Pullman, G. S. (1991), Method for reproducing coniferous plants by somatic embryogenesis using abscisic acid and osmotic potential variation. U.S. Patent No. 5,036,007.

Jalonen, P. and von Arnold, S. (1991), Characterization of embryogenic cell lines of Picea abies in relation to their competence for maturation. Plant Cell Reports, 10, 384-387.

Link, B. M. and Cosgrove, D. J. (1998), Acid-growth response and $\alpha$-expansins in suspension cultures of bright yellow 2 tobacco. Plant Physiology, 118, 907916.

Krook, J.; Vreugdenhil, D.; Dijkema, C. and van der Plas, L. H. W. (1998), Sucrose and starch metabolism in carrto (Dacus carota L.) cell suspensions analysed by ${ }^{13} \mathrm{C}$-labelling: indications for a cytosol and a plastid-localized oxidative pentose phosphate pathway. Journal of Experimental Botany, 49, 19171924.

Maataoui, M. E. L.; Espagnac, H.; Jaber, B. and Lopez, A. A. (1998), Regulation of in vitro callogenesis and organogenesis from Albizzia root explants by carbohydrate source modifications. Journal of Plant Physiology, 152, 494-501. 
Ogita, S.; Kubo, T. and Fushitani, M. (1997), Anatomical characteristics in early embryogenesis from immature embryo of Larix leptolepis. Forest Resource Environment, 35, 45-51.

Ouelhazi, L.; Hamdi, S.; Chénieux, J. C. and Rideau, M. (1994), Cytokinin and auxin-induced regulation of protein synthesis and poly (A) ${ }^{+}$RNA accumulation in Catharanthus roseus cell cultures. Journal of Plant Physiology, 144, 167-174.

Santos, A. L. W.; Silveira, S.; Steiner, N.; Vidor, M. and Guerra, M. P. (2002), Somatic embryogenesis in Parana Pine (Araucaria angustifolia (Bert.) O. Kuntze). Brazilian Archives of Bio/Technology, 45, 97-106.

Schuller, A.; Neß, R. K. and Reuther, G. (2000), Interaction of plant growth regulators and organic $\mathrm{C}$ and $\mathrm{N}$ components in the formation and maturation of Abies alba somatic embryos. Plant Cell Tissue and Organ Culture, 60, 23-31.

Silveira, V.; Steiner, N.; dos Santos, A. L. W.; Nodari, R. O. and Guerra M. P. (2002), Biotechnology tolls in Araucaria angustifolia conservation and improvement: inductive factors affecting somatic embryogenesis. Crop Breeding and Applied Biotechnology, 3, 463-470.

Silveira, V.; Floh, E. I. S.; Handro, W. and Guerra M. P. (2004), Effect of plant growth regulators on the cellular growth and levels of intracellular protein, starch and polyamines in embryogenic suspension cultures of Pinus taeda. Plant Cell Tissue and Organ Culture, 69, 233-249.
Steiner, N.; Vieira, F. do N.; Maldonado, S. and Guerra, M.P. (2005), Carbon Source Affects Morphogenesis and Histodifferentiation of A. angustifolia Embryogenic Cultures. Brazilian archives of Biology and Technology, 48, 896-903.

Tautorus, T. E.; Lulsdorf, M. M.; Kikcio, S. I. and Dunstan, D. I. (1994), Nutrient utilization during bioreactor culture and maturation of somatic embryo of Picea mariana and Picea glauca-engelmanni. In Vitro Cellular Developmental Biology Plant, 30, 5863.

Tremblay, L. and Tremblay, F. M. (1991), Carbohydrate requirements for the development of black spruce (Picea mariana (Mill.) B.S.P.) and red spruce (P. rubens Sarg.) somatic embryos. Plant Cell Tissue and Organ Culture, 27, 95-103.

Veena, S. A. and Rao, K. S. (2000), Calcium-mediated signaling during Sandalwood somatic embryogenesis. Role for exogenous calcium as second messenger. Plant Physiology, 123, 1301-1311.

Wickremesinhe, E. R. M. and Arteca, R. N. (1994), Taxus cell suspension cultures: optimizing growth and production of taxol. Journal of Plant Physiology, 144, 183-188.

Wang, H. L.; Lee P. D.; Chen, W. L.; Huang, D. J. and Su, J. C. (2000), Osmotic stress-induced changes of sucrose metabolism im cultured sweet potato cells. Journal of Experimental Botany, 51, 1991-1999.

Received: May 14, 2007; Revised: February 13, 2008; Accepted: June 17, 2009. 